\title{
Konsep Keadilan dan Sistem Tanggung Jawab Keperdataan dalam Hukum Udara
}

\author{
Ahmad Sudiro \\ Dosen Fakultas Hukum Universitas Tarumanagara Jakarta \\ Jl. Let. Jend. S. Parman No. 1 Jakarta 11440 \\ aspp.1011@gmail.com.
}

\begin{abstract}
The research studies and analyzes the settlement of the indemnification to passengers due to flight accident. The scope of the research involves the obligation of the airlines company, aircraft producer, and insurance company in settling the indemnification to passengers who die, are injured, or disabled due to flight accident in Indonesia using liability theory. This research uses normative law method with qualitative approach which is explanatory and evaluative in form to find the solution to a problem by applying descriptive analysis. The result of the research concludes that, first, the indemnification to the passengers who die, are injured, or disabled due to flight accident is based on the principles of absolute liability. Second, the indemnification from insurance company to the passengers as the first party insurance is paid as the amount of the indemnification incurred as stated in the insurance agreement, based on the premium paid.
\end{abstract}

Key words : Indemnification, passengers, flight accident.

\begin{abstract}
Abstrak
Penelitian ini mengkaji dan menganalisis mengenai penyelesaian ganti kerugian kepada penumpang akibat kecelakaan pesawat udara. Ruang lingkup penelitian ini meliputi kewajiban perusahaan penerbangan, produsen pesawat udara, dan perusahaan asuransi dalam menyelesaikan ganti kerugian kepada penumpang yang meninggal dunia, luka-luka, atau cacat akibat kecelakaan pesawat udara di Indonesia, dengan menggunakan pendekatan teori tanggung jawab (liability). Penelitian ini menggunakan metode penelitian hukum normatif dengan pendekatan kualitatif, yang bersifat eksplanatoris, dan berbentuk evaluatif, yang bertujuan untuk mencari penyelesaian masalah, dengan menerapkan analisis deskriptif. Hasil penelitian ini menyimpulkan, pertama, penyelesaian ganti kerugian kepada penumpang yang meninggal dunia, luka-luka, atau cacat akibat kecelakaan pesawat udara berdasarkan prinsip tanggung jawab mutlak. Kedua, untuk penyelesaian ganti kerugian dari perusahaan asuransi kepada penumpang pesawat udara sebagai tertanggung (first party insurance) dibayarkan sesuai dengan nilai ganti kerugian yang dipertanggungkan dalam perjanjian asuransi, berdasarkan premi yang dibayarkan.
\end{abstract}

Kata kunci : Ganti kerugian, penumpang, kecelakaan pesawat udara. 


\section{Pendahuluan}

Keadilan telah menjadi pokok pembicaraan serius sejak awal munculnya filsafat Yunani. Pembicaraan keadilan memiliki cakupan yang luas, mulai dari yang bersifat etik, filosofis, hukum, sampai pada keadilan sosial. Banyak orang yang berpikir bahwa bertindak adil dan tidak adil tergantung pada kekuatan yang dimiliki. Untuk menjadi adil cukup terlihat mudah, tetapi tentu saja penerapannya tidak mudah dalam kehidupan manusia. ${ }^{1}$ Kata "keadilan" dalam bahasa Inggris adalah "justice" yang berasal dari bahasa latin "iustitia". Kata "justice", pada dasarnya memiliki tiga macam makna yang berbeda yaitu; (1) secara atributif, berarti suatu kualitas yang adil atau fair (justness), (2) sebagai tindakan, berarti tindakan menjalankan hukum atau tindakan yang menentukan hak dan sanksi atau hukuman (judicature), dan (3) orang, yaitu pejabat publik yang berhak menentukan persyaratan sebelum suatu perkara di bawa ke pengadilan (judge, jurist, magistrate). ${ }^{2}$

Secara umum dikatakan bahwa orang yang tidak adil adalah orang yang tidak patuh terhadap hukum (unlawful, lawless) dan orang yang tidak fair (unfair), maka orang yang adil adalah orang yang patuh terhadap hukum (law-abiding) dan fair. Oleh karena tindakan mematuhi hukum adalah adil, maka semua tindakan pembuatan hukum oleh legislatif yang sesuai dengan aturan adalah adil. Tujuan pembuatan hukum yaitu untuk mencapai kemajuan kebahagiaan masyarakat. Dengan demikian, semua tindakan yang cenderung untuk memproduksi dan mempertahankan kebahagiaan masyarakat adalah adil. ${ }^{3}$

Keadilan hanya dapat dipahami jika diposisikan sebagai keadaan yang hendak diwujudkan oleh hukum. Upaya untuk mewujudkan keadilan dalam hukum tersebut merupakan proses dinamis yang memakan banyak waktu. Upaya ini seringkali didominasi oleh kekuatan-kekuatan yang bertarung dalam kerangka umum tatanan politik untuk mengaktualisasikannya. Orang dapat menganggap keadilan sebagai sebuah gagasan atau realitas absolut dan mengasumsikan bahwa pengetahuan dan pemahaman tentangnya hanya bisa didapatkan secara parsial dan melalui upaya filosofis yang sangat sulit. ${ }^{4}$

${ }^{1}$ John R. Boatright, Ethics and the Conduct of Business, $5^{\text {th }}$ Edition, Upper Saddle River, Pearson Education, 2007, hlm. 18.

${ }^{2}$ Hari Chand, Modern Jurisprudence, International Law Book Services, Kuala Lumpur 1994, hlm. 19.

${ }^{3}$ Manuel G. Velazquez, Business Ethics: Concepts and Cases, $5^{\text {th }}$ Edition, Upper Saddle River Prentice Hall, 2002, hlm. 21.

${ }^{4}$ Carl Joachim Friedrich, Filsafat Hukum PerspektifHistoris, Nuansa dan Nusamedia, Bandung, 2004, hlm. 239. 
John Rawls menyatakan bahwa keadilan pada dasarnya merupakan prinsip dari kebijakan rasional yang diaplikasikan untuk konsepsi jumlah dari kesejahteraan seluruh kelompok dalam masyarakat. Untuk mencapai keadilan tersebut, maka rasional jika seseorang memaksakan pemenuhan keinginannya sesuai dengan prinsip kegunaan, karena dilakukan untuk memperbesar keuntungan bersih dari kepuasan yang akan diperoleh oleh anggota masyarakatnya. ${ }^{5}$ Berkaitan dengan konsep keadilan tersebut, maka dalam hukum udara dikenal beberapa sistem tanggung jawab keperdataan, yaitu tanggung jawab berdasarkan adanya unsur kesalahan atau tanggung jawab berdasarkan perbuatan melawan hukum (based on fault liability), tanggung jawab berdasarkan praduga (presumption of liability), dan tanggung jawab mutlak (strict liability).

Prinsip keadilan dipilih karena mengadopsi ide yang lebih realistis dalam menyusun aturan sosial di atas prinsip saling menguntungkan, yang akan meningkatkan efektifitas kerja sama sosial. Dalam konsepsi keadilan sebagai kewajaran (justice of fairness), ditemukan kumpulan prinsip-prinsip yang saling berhubungan untuk mengidentifikasi pertimbangan-pertimbangan yang relevan dan menentukan keseimbangan. Justice of fairness lebih memiliki ide yang lebih umum dan lebih pasti, karena prinsip-prinsip keadilan (principles of justice) sudah dipilih dan sudah diketahui umum. Hal ini berbeda dengan prinsip kegunaan (principle of utility), dimana makna konsep keadilan diambil dari keseimbangan yang tepat antara tuntutan-tuntutan persaingan. Prinsip kegunaan dapat dilihat dari 2 (dua) aspek. Pertama, bahwa masyarakat yang teratur merupakan pola dari kerja sama untuk memperoleh keuntungan timbal balik yang diatur oleh prinsip-prinsip yang dapat dipilih dalam situasi awal sebagai sesuatu yang wajar. Kedua, sebagai efisiensi administrasi dari sumber-sumber sosial untuk memaksimalkan kepuasan dari sistem dari keinginan yang dikonstruksikan oleh pengamat yang netral dan objektif. ${ }^{6}$

\section{Rumusan Masalah}

Berdasarkan uraian pendahuluan di atas, permasalahan dalam tulisan ini: pertama, bagaimana keterkaitan konsep keadilan dengan sistem tanggung jawab keperdataan pada hukum udara? Kedua, bagaimana sistem tanggung jawab

\footnotetext{
${ }^{5}$ John Rawls, A Theory of Justice, Massachusetts: The Belknap Press of Harvard University Press, Cambridge, 1971, hlm. 103.

${ }^{6} \mathrm{Ibid} ., \mathrm{hlm} .104$.
} 
keperdataan tersebut dikaitkan dengan konsep keadilan dari perspektif hukum udara dan perkembangannya?

\section{Tujuan Penelitian}

Penelitian ini ditujukan dalam rangka mengetahui secara lebih seksama dan mendalam mengenai, pertama, keterkaitan antara konsep keadilan dengan sistem tanggung jawab dalam dimensi hukum keperdataan. Kedua, untuk mengetahui sistem tanggung jawab keperdataan tersebut dikaitkan dengan hukum udara dalam hal terjadinya kecelakaan udara.

\section{Metode Penelitian}

Berdasarkan latar belakang, perumusan masalah, serta tujuan penelitian di atas, maka peneliti ini menggunakan metode penelitian hukum normatif dengan pendekatan kualitatif. ${ }^{7}$ Sebagai suatu penelitian hukum normatif, maka penelitian ini berbasis analisis terhadap norma hukum, baik hukum dalam arti peraturan perundang-undangan (law as it is written in the books) maupun hukum dalam arti putusan-putusan pengadilan (law as it is decided by judge through judicial process). Objek yang dikaji dan dianalisis dalam penelitian ini adalah norma hukum, baik yang terdapat dalam peraturan perundang-undangan maupun keputusan-keputusan hakim yang sudah mempunyai kekuatan tetap. Penelitian ini bersifat eksplanatoris yang berbentuk evaluatif dari kombinasi penelitian hukum penerbangan dan asasasas hukum, serta bertujuan untuk mencari penyelesaian masalah. ${ }^{8}$

Peneliti ini menggunakan data sekunder yang diperoleh melalui studi kepustakaan. Bahan penelitian kepustakaan (library research)diambil dari bahan hukum primer, bahan hukum sekunder, dan bahan hukum tersier. ${ }^{9}$ Bahan hukum primer diperoleh dari berbagai peraturan perundang-undangan nasional dan perjanjianperjanjian internasional di bidang penerbangan, serta keputusan-keputusan hakim pengadilan tingkat pertama sampai terakhir mengenai kasus-kasus yang berkaitan dengan masalah penelitian ini. Bahan hukum sekunder diperoleh dari buku-buku (text books) ilmiah tentang hukum penerbangan, hukum perlindungan konsumen,

\footnotetext{
${ }^{7}$ Soerjono Soekanto, Penelitian Hukum, Universitas Indonesia Press, Jakarta, 1986, hlm. 25.

${ }^{8}$ Ibid.

${ }^{9}$ Soerjono Soekanto dan Sri Mamudji, Penelitian Hukum Normatif, Rajawali Grafindo, Jakarta, 2003, hlm. 33.
} 
teori yang berkaitan dengan tanggung jawab dan ganti kerugian, hak dan kewajiban para pihak dalam penyelenggaraan penerbangan, dan lain-lainnya yang relevan dengan penelitian ini. Bahan hukum tersier sebagai bahan penunjang yang memberikan petunjuk terhadap bahan hukum primer dan bahan hukum sekunder, diperoleh dari kamus hukum dan peraturan hukum penerbangan, kamus umum, jurnal hukum, surat kabar, majalah hukum, dan hasil penelitian yang berkaitan dengan penyelesaian ganti kerugian dan tanggung jawab hukum perusahaan penerbangan dan produsen pesawat udara serta perusahaan asuransi terhadap penumpang akibat kecelakaan pesawat udara dalam penyelenggaraan penerbangan nasional dan internasional. ${ }^{10}$

Untuk mendukung dan melengkapi analisis data sekunder tersebut, peneliti melakukan wawancara dengan berbagai informan atau nara sumber yang berkompeten dan dinilai memahami konsep-konsep pemikiran yang terdapat dalam data sekunder, serta para pihak yang terkait dengan kegiatan penyelenggaraan penerbangan, antara lain Kepala Bagian Direktorat Perhubungan Udara Kementerian Perhubungan RI, Ketua Komisi III dan Komisi V Dewan Perwakilan Rakyat Republik Indonesia (DPR-RI), Pemandu lalu lintas udara (Air Traffic Control/ ATC), Legal Manager beberapa perusahaan penerbangan nasional antara lain PT. Garuda Indonesia, PT. Merpati Nusantara, PT. Mandala Airlines, PT. Lion Air sebagai pengangkut, perusahaan pembuat pesawat udara sebagai produsen, penumpang sebagai konsumen, Ketua Asosiasi Perusahaan Penerbangan Nasional Indonesia (Indonesian National Air Carriers Association/ INACA), dan para pakar hukum penerbangan antara lain H. Priyatna Abdurrasyid dan K. Martono. Peneliti dalam melakukan wawancara dengan berbagai nara sumber yang berkompeten dan memahami konsep pemikiran dalam permasalahan penelitian ini menggunakan pedoman wawancara dengan teknik wawancara tidak berstruktur yang bersifat terfokus. ${ }^{11}$

\section{Hasil Penelitian dan Pembahasan}

Menurut Aristoleles, keadilan harus dipahami dalam pengertian kesamaan, tetapi dibedakan antara kesamaan numerik dan kesamaan proporsional. ${ }^{12}$ Kesamaan

\footnotetext{
${ }^{10}$ Ibid.

${ }^{11}$ Soerjono Soekanto, Penelitian ..., Op. Cit., hlm. 26.

${ }^{12}$ Aristoteles, "Nicomachean Ethics", Translated by: W. D. Ross, http://bocc.ubi.pt/pag/Aristotelesnicomachaen. html, 20 Oktober 2010, hlm. 2.
} 
numerik menyamakan setiap manusia sebagai satu unit, sedangkan kesamaan proporsional memberi setiap orang apa yang menjadi haknya sesuai dengan kemampuan dan prestasinya. ${ }^{13}$ Selanjutnya Aristoteles membedakan jenis keadilan distributif dan keadilan korektif. Dalam keadilan distributif, imbalan yang sama rata akan diberikan atas pencapaian yang sama rata, sedangkan pada keadilan korektif yang menjadi persoalan yaitu ketidaksetaraan yang disebabkan adanya pelanggaran kesepakatan, akan dikoreksi dan dihilangkan. ${ }^{14}$

Keadilan distributif berfokus pada distribusi, biaya, kekayaan, dan barang lainnya yang dapat diperoleh dalam masyarakat. Distribusi yang adil harus sesuai dengan nilai kebaikan bagi masyarakat. Sedangkan dalam keadilan korektif berfokus pada pembetulan sesuatu yang salah. Apabila suatu kesalahan dilakukan yang mengakibatkan kerugian kepada pihak lain, maka keadilan korektif berusaha memberikan ganti kerugian yang wajar dan memadai kepada korban akibat adanya kesalahan tersebut. Oleh karena ketidakadilan dapat mengakibatkan terganggunya kesetaraan yang sudah terbentuk dengan mapan, dan keadilan korektif bertugas membangun kembali kesetaraan tersebut. ${ }^{15}$

Keadilan sebagai bagian dari nilai sosial memiliki makna yang sangat luas, bahkan pada suatu titik dapat bertentangan dengan hukum sebagai salah satu tata nilai sosial, karena keadilan merupakan kebajikan yang berkaitan dengan hubungan antar manusia. Seseorang dapat dinyatakan berlaku adil, jika mengambil sesuai dengan bagian yang semestinya. Oleh karena kepentingan utama dalam keadilan yaitu jaminan stabilitas hidup manusia, dan keseimbangan antara kehidupan pribadi dengan kehidupan bersama. ${ }^{16}$

John Rawls, berpendapat bahwa keadilan sebagai kebaikan utama dari hadirnya institusi-institusi sosial (social institutions). Namun kebaikan bagi seluruh masyarakat tidak dapat mengesampingkan atau mengganggu rasa keadilan dari setiap orang yang telah memperoleh rasa keadilan, khususnya masyarakat yang lemah. Oleh karena itu harus terdapat keseimbangan antara kepentingan pribadi dengan kepentingan bersama. Untuk menghindari terjadinya benturan antara kepentingan pribadi dengan kepentingan bersama tersebut diperlukan adanya ketentuan hukum yang mengaturnya. Masyarakat akan mentaati ketentuan hukum, jika aturannya

\footnotetext{
${ }^{13}$ Misalnya pernyataan bahwa "Semua warga negara mempunyai kedudukan yang sama di depan hukum".

${ }^{14}$ Aristoteles, "Nicomachean ...".

${ }^{15}$ Carl Joachim Friedrich, Filsafat Hukum ..., hlm. 240.

${ }^{16}$ Aristoteles, "Nicomachean ...", Op. Cit., hlm. 3.
} 
dapat meletakkan prinsip-prinsip keadilan, karena pada dasarnya hukum harus menjadi penuntun agar orang dapat mengambil posisi yang adil dengan tetap memperhatikan kepentingan individunya, dan bertindak proposional sesuai dengan haknya serta tidak melanggar hukum yang berlaku. Dengan demikian keadilan sangat berkaitan dengan hak dan kewajiban para pihak dalam melaksanakan kesepakatan perjanjian sebagai bentuk tanggung jawabnya. ${ }^{17}$

KUHPerdata Indonesia mengatur mengenai prinsip tanggung jawab ini berkaitan dengan masalah penyelesaian ganti kerugian dalam Pasal 1365 KUHPerdata, yang menyatakan bahwa “Tiap perbuatan yang melanggar hukum, dan membawa kerugian kepada seorang lain, mewajibkan orang yang karena salahnya menerbitkan kerugian itu, mengganti kerugian tersebut" ${ }^{18}$ Pasal ini terkenal dengan pasal mengenai tanggung jawab berdasarkan atas kesalahan (based on fault liability), atau biasa disebut pasal perbuatan melawan hukum dengan beban pembuktian terletak pada korban sebagai penggugat. Hal ini sejalan dengan Pasal 1865 KUHPerdata yang menyatakan"19: "Setiap orang yang mendalilkan bahwa ia mempunyai sesuatu hak, atau guna meneguhkan haknya sendiri maupun membantah sesuatu hak orang lain, menunjuk pada suatu peristiwa, diwajibkan membuktikan adanya hak atau peristiwa tersebut".

Ketentuan perbuatan melawan hukum lahir karena adanya prinsip barang siapa melakukan perbuatan yang membawa kerugian kepada orang lain mewajibkan orang yang karena salahnya menerbitkan kerugian untuk mengganti kerugian tersebut. ${ }^{20}$ Pada dasarnya prinsip ini merupakan turunan dari teori Corrective Justice, yang mengajarkan bahwa setiap orang harus melindungi hak-haknya dan harus dipulihkan keadaannya agar ada keseimbangan antara keadilan dan kepastian hukum yang merupakan tujuan hukum. Oleh karena berdasarkan prinsip Corrective Justice, dalam penyelesaian pembayaran ganti kerugian terhadap korban sebagai bentuk tanggung jawab hukum, maka semestinya dapat mengembalikan kepada keadaan semula sebelum terjadinya perbuatan melawan hukum kepada korban tersebut. ${ }^{21}$

Pasal 1365 KUHPerdata menentukan bahwa kewajiban pelaku perbuatan melawan hukum untuk membayar ganti kerugian, tetapi tidak ada pengaturan lebih

${ }^{17}$ John Rawls, A Theory...., Op. Cit., hlm. 21.

${ }^{18}$ R. Subekti dan R. Tjitrosudibio (Penj.), Kitab Undang-undang Hukum Perdata (Burgerlijk Wetboek), Pradnya Paramita, Jakarta, 1992, hlm. 346.

${ }^{19}$ Ibid., hlm. 475.

${ }^{20}$ Rosa Agustina, Perbuatan Melawan Hukum, Fakultas Hukum Universitas Indonesia, Jakarta, 2003, hlm. 325.

${ }^{21}$ Ibid., hlm. 329. 
lanjut mengenai ganti kerugian tersebut. Selanjutnya Pasal 1371 ayat (2) KUHPerdata sedikit memberikan pedoman untuk penyelesaian pembayaran ganti kerugian itu dengan menyatakan bahwa:22 "Penggantian kerugian ini dinilai menurut kedudukan dan kemampuan kedua belah pihak, dan menurut keadaan".

Pedoman penyelesaian pembayaran ganti kerugian selanjutnya dapat ditemukan dalam Pasal 1372 ayat (2) KUHPerdata yang menyatakan bahwa: ${ }^{23}$ "Dalam menilai satu dan lain hal, hakim harus memperhatikan berat ringannya penghinaan, begitu pula pangkat, kedudukan dan kemampuan kedua belah pihak". Dasar penilaian pembayaran ganti kerugian kepada korban sebagai bentuk tanggung jawab hukum seperti di atas, dalam hukum udara diatur pada Pasal 24 ayat (2) Ordonansi Pengangkutan Udara No. 100 Tahun 1939 (Luchtvervoer Ordonnantie Staatsblad 1939 No. 100), yang menyatakan: “...Apabila luka tersebut mengakibatkan kematian, maka suami atau isteri dari yang meninggal dunia, anak-anaknya, atau orang tuanya, yang menjadi tanggungan dari yang meninggal dunia dapat menuntut ganti kerugian, yang dinilai sesuai dengan kedudukan dan kekayaan mereka yang bersangkutan serta sesuai dengan keadaannya." Dengan demikian besarnya jumlah pembayaran ganti kerugian ditetapkan berdasarkan penaksiran, dimana diusahakan agar pihak korban yang menderita kerugian semaksimal mungkin dapat dikembalikan pada keadaan sebelum terjadinya perbuatan melawan hukum. Selain itu unsur kerugian dalam perbuatan melawan hukum harus dibuktikan, karena hal ini untuk menentukan jumlah pembayaran ganti kerugian akibat terjadinya suatu perbuatan melawan hukum tersebut. Besarnya nilai kerugian itu tidak ditentukan oleh para pihak sendiri, akan tetapi ditentukan oleh hakim yang mengadili perkara tersebut sesuai dengan keadaan masing-masing pihak.

Pengertian perbuatan melawan hukum oleh Hoge Raad ditafsirkan secara sempit sebelum 1919. Hoge Raad memberikan batasan perbuatan melawan hukum, sebagai berbuat atau tidak berbuat sesuatu yang melanggar hak orang lain atau bertentangan dengan kewajiban hukum pelaku yang telah diatur oleh undang-undang. Ajaran penafsiran sempit ini sebenarnya bertentangan dengan doktrin yang dikemukakan oleh para sarjana. Misalnya, pendapat Molegraaff yang saat itu bertentangan dengan Hoge Raad. Menurut Molegraaff, suatu perbuatan melawan hukum tidak hanya melanggar undang-undang, tetapi juga melanggar ketertiban umum atau melanggar

\footnotetext{
${ }^{22}$ R. Subekti dan R. Tjitrosudibio (Penj.), Kitab ..., Op. Cit., hlm. 347.

${ }^{23}$ Ibid., hlm. 348.
} 
kaidah kesusilaan yang baik, dan melanggar kepatutan yang berlaku di masyarakat. $^{24}$

Penafsiran secara sempit dari Hoge Raad tersebut berlangsung sampai tahun 1919, karena sejak itu Hoge Raad mulai menafsirkan secara luas mengenai pengertian perbuatan melawan hukum. Ajaran secara luas itu ditandai dengan putusan the Hoge Raad der Nederland (the Dutch Supreme Court) dalam kasus Lindenbaum v. Cohen, 31 Januari 1919. Pada perkara ini, Hoge Raad menyatakan bahwa pada dasarnya perbuatan melawan hukum harus diartikan sebagai berbuat atau tidak berbuat yang bertentangan dengan melanggar hak subjektif orang lain, kewajiban hukum pelaku, kaidah kesusilaan, dan kepatutan yang berlaku dalam masyarakat. ${ }^{25}$

Sejak putusan Hoge Raad tersebut, peradilan selalu menafsirkan pengertian perbuatan melawan hukum secara luas, yaitu dari pengertian yang sebelumnya merupakan "perbuatan yang bertentangan dengan kewajiban hukum pembuat yang telah diatur dalam undang-undang", kemudian pengertiannya berubah men-jadi "perbuatan yang bertentangan dengan hak orang lain, atau bertentangan dengan kesusilaan yang baik, atau bertentangan dengan kepatutan yang harus diperhatikan dalam pergaulan hidup terhadap orang lain atau benda". Sedangkan barang siapa karena salahnya dan menimbulkan kerugian kepada orang lain, maka berkewajiban membayar ganti kerugian sebagai bentuk tanggung jawab hukum. ${ }^{26}$

Konsep modern tentang tanggung jawab keperdataan (civil liability) secara umum menyatakan bahwa unsur kesalahan pada seseorang yang menyebabkan timbulnya kerugian pada orang lain merupakan syarat mutlak bagi adanya perbuatan melawan hukum. Teori bahwa tiada tanggung jawab tanpa kesalahan (no lia-bility without fault) menjadi dogma yang berlaku umum. ${ }^{27}$ Unsur kesengajaan dalam perbuatan melawan hukum dianggap telah ada, jika dengan perbuatan yang dilakukan dengan sengaja tersebut telah menimbulkan konsekuensi tertentu terhadap fisik dan/atau mental atau harta benda korban, meskipun belum merupakan kesengajaan untuk melukai diri korban tersebut.

Oleh karena itu penerapan tanggung jawab perusahaan angkutan udara sebagai pengangkut dalam konvensi Warsawa 1929, yang dikenal dengan presumption of

${ }^{24}$ M. A. Moegni Djojodiharjo, Perbuatan Melawan Hukum, Pradnya Paramita, Jakarta, 1979, hlm. 28.

${ }^{25}$ R. Setiawan, "Empat Kriteria Perbuatan Melawan Hukum dan Perkembangan Dalam Yurisprudensi”, Varia Peradilan No. 16/ Tahun 11, Januari, 1987, hlm. 176.

${ }^{26}$ M. A. Moegni Djojodihardjo, Perbuatan ..., Op. Cit., hlm. 27.

${ }^{27} \mathrm{~J}$. G. Fleming, The Law of Torts, $5^{\text {th }}$ Edition, The Law Book Company, Sydney, 1977, hlm. 8. 
liability atau presumption of negligence or fault, pada dasarnya berasal dari sistem tanggung jawab berdasarkan unsur kesalahan (based on fault liability) atau tanggung jawab berdasarkan perbuatan melawan hukum dengan sistem pembuktian terbalik, sehingga dalam sistem tanggung jawab ini kewajiban untuk membuktikan ada atau tidak adanya unsur kesalahan/kelalaian dibebankan kepada tergugat. Sistem presumption of liability yang terdapat pada konvensi Warsawa 1929 tersebut diberlakukan baik untuk tanggung jawab pengangkut terhadap penumpang, bagasi tercatat maupun kargo. ${ }^{28}$

Perbedaan yang utama antara sistem tanggung jawab berdasarkan unsur kesalahan atau tanggung jawab berdasarkan perbuatan melawan hukum dengan sistem presumption of liability yaitu bahwa di dalam tanggung jawab berdasarkan praduga beban pembuktian beralih dari penggugat kepada tergugat. Jadi berdasarkan sistem ini yang diterapkan di dalam konvensi Warsawa 1929 dan Ordonansi Pengangkutan Udara No. 100 Tahun 1939, maka pengangkut sebagai pelaku usaha adalah prima facie bertanggung jawab atas kerugian yang timbul kecuali dapat membuktikan sebaliknya bahwa pihaknya telah mengambil semua tindakan yang diperlukan untuk menghindari terjadinya kerugian itu atau hal tersebut tidak mungkin dapat dilakukannya.

Namun dalam perkembangan sistem tanggung jawab hukum selanjutnya, muncul tanggung jawab mutlak yang pada awalnya merupakan konsekuensi dari ajaran $a$ man acts at his peril atau he who breaks must pay, ${ }^{29}$ yang artinya bahwa barang siapa berbuat dan merugikan orang lain, maka harus bertanggung jawab. Oleh karena tugas utama hukum dalam masyarakat, antara lain memelihara kerukunan hubungan antara individu-individu dengan menyedia-kan suatu cara penyelesaian yang diharapkan dapat diterima para pihak untuk mencegah pembalasan dendam. ${ }^{30}$ Dalam hal ini Roscoe Pound menyatakan bahwa: ${ }^{31}$

In the beginnings of the law the idea is simply to keep the peace. In primitive law justice, in the sense of the end of the legal system, was a device to keep the peace. Whatever served to avert private of justice. The law existed as abody of rules by which controversies were adjusted peaceably. hlm. 167.

${ }^{28}$ R. H. Mankiewicz, The Liability Regimes of the International Air Carrieage, Deventer-Kluwer, Nederland, 1981,

${ }^{29}$ William L. Prosser, Handbook of the Law of Torts, $4^{\text {th }}$ Edition, West Publishing Company, St. Paul Minnesotta, 1981, hlm. 492.

${ }^{30}$ J. G. Fleming, The Law ..., Op. Cit., hlm. 7.

${ }^{31}$ Roscoe Pound, "The End of Law as Developed in Legal Rules and Doctrines", 27 Harvard Law Review, (1942), hlm. 198-199. 
Dalam masyarakat modern, tanggung jawab mutlak atau tanggung jawab yang tidak berdasarkan unsur kesalahan harus dipandang dari pertimbangan nilai sosial secara luas (a broad social value judgement), bahwa seseorang yang melakukan kegiatan untuk memperoleh keuntungan bagi dirinya sendiri harus menanggung segala risiko akibat dari kegiatannya tersebut. ${ }^{32}$ Dengan demikian kewajiban pengangkut merupakan konsekuensi dari kewajiban kontraktual, yaitu mengangkut penumpang dan/atau bagasi atau kargo sampai di tempat tujuan yang telah disepakati dengan selamat.

Apabila selama dalam penyelenggaraan pengangkutan, ternyata penumpang mengalami kecelakaan (meninggal dunia, luka-luka, atau cacat) dan bagasi/kargo hilang atau rusak, maka sudah cukup membuktikan adanya pelanggaran perjanjian atau wanprestasi. Kewajiban pengangkut adalah menjamin bahwa penumpang dan/ atau bagasi atau kargo yang diangkutnya sampai di tempat tujuan dengan selamat. ${ }^{33}$ Jadi kewajiban pengangkut untuk mencapai sesuatu hasil (obligation de resultant), dan bukan hanya untuk sekedar menyelenggarakan kegiatan pengangkutan (obligation de moyens). Dalam mengajukan gugatan pertanggungjawaban hukum, maka pengguna jasa pengangkutan cukup hanya membuktikan telah adanya perjanjian pengangkutan dengan disertai fakta bahwa penggugat tersebut tidak sampai di tempat tujuan dengan selamat. Oleh karena sistem tanggung jawab mutlak merupakan suatu tanggung jawab tanpa keharusan untuk membuktikan adanya unsur kesalahan atau sistem tanggung jawab yang memandang unsur kesalahan sebagai suatu yang tidak relevan untuk dipermasalahkan lagi, apakah pada kenyataannya ada atau tidak ada dalam penerapan sistem tanggung jawab hukum tersebut.

Selain itu dalam perkembangan sistem tanggung jawab mutlak ini, para pakar hukum udara ada yang menggunakan istilah absolute liability dan strict liability. Istilah absolute liability digunakan untuk pertama kalinya oleh Sir John Salmond dalam bukunya berjudul The Law of Torts tahun 1907, yang menyatakan:34

${ }^{32}$ Glanville Williams and B.A. Hepple, Foundations of the Law of Tort, Butterworths, London, 1986, hlm. 108.

${ }^{33}$ Pasal 468 ayat (1) KUHD tentang pengangkutan barang, menyatakan bahwa "Perjanjian pengangkutan mewajibkan pengangkut menjaga keselamatan barang-barang yang diangkutnya sejak barang diterima sampai diserahkan". Sedangkan pada Pasal 522 Ayat (1) KUHD tentang pengangkutan orang, menyatakan bahwa "Perjanjian pengangkutan mewajibkan pengangkut menjaga keselamatan penumpang sejak penumpang masuk kapal sampai meninggalkan kapal".

${ }^{34}$ John Salmond, The Law of Torts, $1^{\text {st }}$ Edition, Sweet \& Maxwell, London, 1907, hlm. 11. 
The rule that mens rea in one or other of its two forms -wrongful intent or negligence is an essential condition of civil liability for a tort, is subject important exceptions. These exceptional cases in which liability is independent of intention or negligence may be conveniently distinguished as cases of absolute liability.

Sedangkan istilah strict liability dikemukakan oleh W. H. Winfield pada tahun 1926 dalam sebuah artikel yang berjudul "The Myth of Absolute Liability". ${ }^{35}$ Menurut Sir John Salmond, putusan pengadilan dalam kasus Rylands v. Fletcher tahun 1866, adalah salah satu contoh terpenting tentang absolute liability yang dikenal dalam sistem hukum Anglo -Saxon. ${ }^{36}$ Dalam putusannya hakim Blackburn pada perkara tersebut menyatakan: “. . but the question arises whether the duty which the law casts upon him under such circumstances is an absolute duty to keep it at his peril or ...". ${ }^{37}$ Menurut putusan hakim tersebut, bahwa seseorang yang melakukan suatu perbuatan atau kegiatan harus menanggung sendiri risikonya, dan bertanggung jawab terhadap kerugian yang timbul, serta tidak tergantung pada adanya kesalahan atau kelalaian di pihaknya. Namun W.H. Winfield berpendapat bahwa putusan hakim dalam kasus Rylands v. Fletcher belum dapat dikategorikan sebagai contoh dari absolute liability, karena pada kasus itu masih ada beberapa perkecualian yang dapat membebaskan tergugat dari tanggung jawab hukumnya, sehingga lebih tepat jika putusan hakim itu disebut strict liability. Dalam kasus ini W. H. Winfield menyatakan: ... the description of the rule in Rylands $v$. Fletcher as an example of absolute liability in tort is unhappy in view of some half dosen exceptions which are admitted as qualifications of it. Strict liability seems to be a better term. Though stated as a rule of absolute liability, there are so many exceptions to it that it is doubtful whether is much of the rule left. The liability may be strict, but it is not absolute as the exceptions to the rule indicated by Blackburn J. himself show. ${ }^{38}$

Dalam hal ini, Fridman sependapat dengan W. H. Winfield bahwa tidak tepat untuk menyebut absolute liability dalam kasus Rylands v. Fletcher, karena masih banyak pembatasan dalam pelaksanaannya, meskipun tidak diperlukan adanya unsur kesalahan/kelalaian. Selanjutnya Fridman menyatakan, bahwa suatu sistem tanggung jawab dengan kesalahan bukan sebagai faktor yang menentukan, tetapi disertai dengan perkecualian-perkecualian yang sudah umum diakui sebagai alasan untuk dapat membebaskan tanggung jawab, ${ }^{39}$ maka lebih tepat disebut strict liability. ${ }^{40}$ Dalam

\footnotetext{
${ }^{35}$ W. H. Winfield, "The Myth of Absolute Liability”, 42 Law Quarterly Review, 1926, hlm. 37.

${ }^{36}$ John Salmond, The Law ..., Op. Cit., hlm. 19.

${ }^{37}$ Ibid.

${ }^{38}$ W. H. Winfield, “The Myth ...”, Op. Cit., hlm. 51.

${ }^{39}$ Misalnya force majeure, contributory negligence, act of god, perbuatan pihak ketiga, tindakan penguasa, perang, huru-hara, kesalahan pengiriman barang, cacat barang dari semula.

${ }^{40}$ G. H. L. Fridman, Introduction to the Law of Torts, Butterworths, London, 1978, hlm. 38.
} 
menjelaskan tentang absolute liability sebagai sistem tanggung jawab tanpa adanya kemungkinan untuk membebaskan diri, Mircea Mateesco Matte membedakan antara istilah objective liability dengan absolute liability. ${ }^{41}$ Menurutnya, pada objective liability dimungkinkan ter-gugat membebaskan diri dari tanggung jawabnya dalam hal force majeure atau contributory negligence of a third party (kerugian disebabkan oleh kesalahan pihak ketiga), sedangkan dalam absolute liability hal itu tidak dimungkinkan. Namun Matte juga menyatakan bahwa pembedaan tersebut hanya bersifat teoritis saja.

Meskipun baik secara teoritis maupun praktis sulit mengadakan pembedaan yang tegas di antara kedua istilah absolute liability dengan strict liability, tetapi Bin Cheng menunjukkan adanya perbedaan pokok antara kedua istilah tersebut. Pada strict liability perbuatan yang menyebabkan kerugian yang dituntut harus dilakukan oleh orang yang bertanggung jawab, sehingga terdapat hubungan kausalitas antara orang yang bertanggung jawab dengan kerugian tersebut. Dalam strict liability, semua hal yang biasanya dapat membebaskan tanggung jawab (usual defences) tetap diakui, kecuali hal-hal yang mengarah pada pernyataan tidak bersalah (absence offault), karena kesalahan tidak lagi diperlukan dalam penerapan sistem tanggung jawab hukum ini.

Pada absolute liability akan muncul kapan saja keadaan yang menimbulkan tanggung jawab tersebut, tanpa mempermasalahkan oleh siapa atau bagaimana terjadinya suatu kerugian, sehingga tidak disyaratkan adanya hubungan kausalitas antara orang yang bertanggung jawab dengan timbulnya kerugian. Dalam hal ini faktor-faktor yang biasanya dapat dijadikan alasan untuk membebaskan diri dari tanggung jawab tidak berlaku, kecuali yang dinyatakan secara tegas. Namun tidak berarti bahwa pada absolute liability tidak terdapat hal-hal yang membebaskan tanggung jawab, hanya saja hal itu harus dinyatakan secara khusus. ${ }^{42}$ Misalnya konvensi-konvensi yang baik secara tegas maupun diam-diam memberlakukan absolute liability dengan menyebutkan secara khusus hal-hal yang dapat membebaskan tanggung jawab, seperti Rome Convention 1952 (Damage Caused by Foreign Aircraft to Third Parties on the Surface), Brussels Convention 1962 (The Liability of Operators of Nuclear Ships), Vienna Convention 1963 (Civil Liability for Nuclear Damage) dan Montreal Interim Agreement 1966. ${ }^{43}$ Dalam hal ini, Bin Cheng menyatakan: ${ }^{4}$

${ }^{41}$ Mircea Mateesco Matte, “Should the Warsaw System be Denounced or Integrated?”, 5 Annals of Air and Space Law, (1980), hlm. 201.

${ }^{42}$ Ibid.

${ }^{43}$ Konvensi Roma Tahun 1952 menetapkan hal-hal yang membebaskan tanggung jawab yaitu: contributory negligence/ sebagian atau seluruhnya (Pasal 6), armed conflict, civil disturbance, act of public aurthority (Pasal 5).

${ }^{44}$ Bin Cheng, "A Reply to Charges of Having Inter Alia Misuse the Term Absolute Liability in Relation to the 
In absolute liability, however, once the prescribed conditions are met, liability arises "absolutely" in the sense that none of the usual defences is available, but this does not mean that no exceptions to such liability can be prescribed. absolute liability can, therefore, also provide for exceptions in specified circumstances.

Selain itu berdasarkan penjelasan dari Sekretaris Komisi Hukum Organisasi Penerbangan Sipil Internasional (Legal Committee International Civil Aviation Organization) ICAO), menyatakan bahwa istilah absolute liability tidak tepat jika masih diperbolehkan adanya perkecualian, sehingga untuk sistem tanggung jawab yang masih diperkenankan adanya hal-hal untuk membebaskan diri dari tanggung jawab hukum maka lebih tepat disebut strict liability. ${ }^{45}$ Di pihak lain, mereka menunjuk pada konvensi Roma 1952 yang sudah dikenal sebagai konvensi yang memberlakukan sistem absolute liability, tetapi masih memperkenankan hal-hal tertentu yang dapat membebaskan tanggung jawabnya. Selanjutnya dalam konvensi Brusels 1962 dan konvensi Viena 1963 yang berkaitan dengan pengaturan tanggung jawab operator dalam pengangkutan bahan nuklir, meskipun dimungkinkan adanya pembebasan tanggung jawab dalam hal-hal tertentu, tetapi dalam teks resmi bahasa Inggris ternyata diguna-kan istilah absolute liability.

Oleh karena itu tidak ada ukuran yang pasti di dalam membedakan kedua istilah tersebut. Namun dalam praktek terdapat indikasi yang diterima secara umum bahwa pada sistem strict liability, pihak yang bertanggung jawab dapat membebaskan diri berdasarkan semua alasan yang sudah dikenal secara umum (conventional defences), seperti kesalahan dari korban, keadaan sangat terpaksa, keadaan perang, tindakan penguasa, keadaan cacat dari barang, dan sebagainya. Sedangkan pada sistem absolute liability, alasan-alasan umum pembebasan tersebut tidak berlaku kecuali yang secara khusus dinyatakan dalam instrumen-instrumen tertentu seperti konvensi, undangundang, dan lain-lainnya, serta tanggung jawab hukum ini akan timbul pada saat kerugian terjadi tanpa mempersoalkan siapa penyebabnya dan bagaimana terjadinya.

1966 Montreal Inter Carrier Agreement in My Plea for an Integrated System of Aviation Liability", 6 Annals of Air and Space Law, (1981), hlm.4.

${ }^{45}$ International Civil Aviation Organization Document 8839-LC/158-1, (1981), hlm. 116-117. Komisi Hukum ini membentuk "Subcommittee on Revision of the Warsaw Convention as amended by the Hague Protocol", dan menghasilkan draft Protocol Guatemala City 1971. 


\section{Penutup}

Bersandar pada hasil pembahasan dan analisis di atas, dapat ditarik kesimpulan: pertama, bahwa penyelesaian ganti kerugian kepada penumpang yang meninggal dunia, luka-luka, atau cacat akibat kecelakaan pesawat udara berdasarkan prinsip tanggung jawab mutlak. Kedua, untuk penyelesaian ganti kerugian dari perusahaan asuransi kepada penumpang pesawat udara sebagai tertanggung (first party insurance) dibayarkan sesuai dengan nilai ganti kerugian yang dipertanggungkan dalam perjanjian asuransi, berdasarkan premi yang dibayarkan.

Adapun saran yang dapat disampaikan dalam penelitian ini adalah bersandar pada konsepsi keadilan kompensasi (compensatory justice), maka perusahaan pengangkutan udara sebagai pelaku usaha yang melakukan kesalahan/kelalaian dalam kegiatan usahanya sehingga menimbulkan kerugian pihak lain, mempunyai kewajiban moral dan tanggung jawab hukum untuk membayar kompensasi kepada pihak yang menderita kerugian tersebut berlandaskan asas keadilan. Penyelesaian tanggung jawab hukum dengan membayar kompensasi kepada korban sebagai pihak yang menderita kerugian itu, bertujuan semaksimal mungkin untuk mengembalikan kondisi korban seperti sebelum terjadinya kerugian tersebut, sehingga tercipta keadilan bagi para pihak. Dengan demikian, prinsip keadilan memberikan hak dan kewajiban yang sama kepada setiap orang yang menjadi kepentingan hak dan kewajibannya berkaitan dengan penerapan sistem tanggung jawab keperdataan dalam hukum udara.

\section{Daftar Pustaka}

Agustina, Rosa, Perbuatan Melawan Hukum, Fakultas Hukum Universitas Indonesia, Jakarta, 2003.

Aristoteles, "Nicomachean Ethics", Translated by: W. D. Ross, http://bocc.ubi.pt/ pag/Aristoteles-nicomachaen.html, 20 Oktober 2010.

Boatright, John R., Ethics and the Conduct of Business, $5^{\text {th }}$ Edition, Upper Saddle River: Pearson Education, 2007.

Chand, Hari, Modern Jurisprudence, International Law Book Services, Kuala Lumpur, 1994.

Cheng, Bin, "A Reply to Charges of Having Inter Alia Misuse the Term Absolute Liability in Relation to the 1966 Montreal Inter Carrier Agreement in My Plea for an Integrated System of Aviation Liability", 6 Annals of Air and Space Law, 1981. 
Djojodiharjo, M. A. Moegni, Perbuatan Melawan Hukum, Pradnya Paramita, Jakarta, 1979.

Fleming, J. G., The Law of Torts, $5^{\text {th }}$ Edition, The Law Book Company, Sydney, 1977.

Fridman, G. H. L., Introduction to the Law of Torts, Butterworths, London, 1978.

Friedrich, Carl Joachim, Filsafat Hukum Perspektif Historis, Nuansa dan Nusamedia, Bandung, 2004.

Mankiewicz, R. H., The Liability Regimes of the International Air Carrieage, DeventerKluwer, Nederland, 1981.

Matte, Mircea Mateesco, "Should the Warsaw System be Denounced or Integrated?", 5 Annals of Air and Space Law, 1980.

Pound, Roscoe, "The End of Law as Developed in Legal Rules and Doctrines", 27 Harvard Law Review, 1942.

Prosser, William L., Handbook of the Law of Torts, $4^{\text {th }}$ Edition, West Publishing Company, St. Paul Minnesotta, 1981.

Rawls, John, A Theory of Justice, Cambridge, The Belknap Press of Harvard University Press, Massachusetts, 1971.

Salmond, John, The Law of Torts, $1^{\text {st }}$ Edition, Sweet \& Maxwell, London, 1907.

Setiawan, R., “Empat Kriteria Perbuatan Melawan Hukum dan Perkembangan Dalam Yurisprudensi", Varia Peradilan No. 16/ Tahun 11, Januari 1987.

Subekti, R. dan R. Tjitrosudibio, Kitab Undang-undang Hukum Perdata (Burgerlijk Wetboek), Pradnya Paramita, Jakarta, 1992.

Velazquez, Manuel G., Business Ethics: Concepts and Cases, $5^{\text {th }}$ Edition, Upper Saddle River: Prentice Hall, 2002.

Williams, Glanville and B.A. Hepple, Foundations of the Law of Tort, Butterworths, London, 1986.

Winfield, W. H., “The Myth of Absolute Liability”, 42 Law Quarterly Review, 1926. 